\title{
Variations in Personal Protective Equipment Preparedness in Intensive Care Units during the COVID- 19 Pandemic: A Survey of Asia-Pacific Countries
}

Title Page

On Behalf of the SPARTAN Collaborative - Small Projects, Audits, Research Trials - Australia/New Zealand

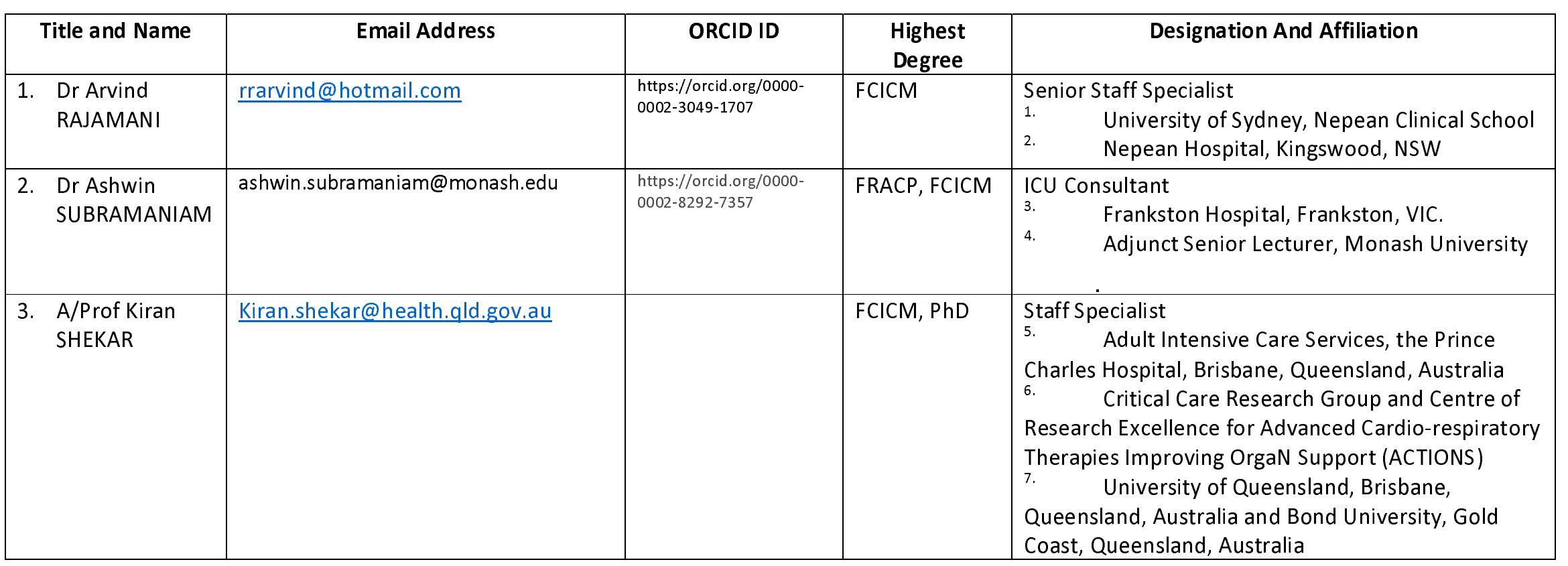




\begin{tabular}{|c|c|c|c|c|}
\hline Title and Name & Email Address & ORCID ID & $\begin{array}{l}\text { Highest } \\
\text { Degree }\end{array}$ & Designation And Affiliation \\
\hline 4. Dr Jumana HAJI & drjyhaji@gmail.com & & $\begin{array}{l}\text { MD } \\
\text { (Anesthesia) }\end{array}$ & $\begin{array}{l}\text { ECMO program director, Consultant anesthesia and } \\
\text { critical care } \\
8 . \quad \text { Aster CMI hospital Bangalore }\end{array}$ \\
\hline $\begin{array}{l}\text { 5. Dr Jinghang } \\
\text { LUO }\end{array}$ & Jinghangluo@hotmail.com & & $\begin{array}{l}\text { MBBS, MMed } \\
\text { (ClinEpi) }\end{array}$ & $\begin{array}{l}\text { Basic Physician Trainee } \\
9 . \quad \text { Western Health, VIC }\end{array}$ \\
\hline $\begin{array}{l}\text { 6. A/Prof Shailesh } \\
\text { BIHARI }\end{array}$ & biharishailesh@gmail.com & $\begin{array}{l}\text { https://orcid.org/0000- } \\
0001-7553-8620\end{array}$ & FClCM, PhD & $\begin{array}{l}\text { ICU consultant } \\
\text { 10. } \quad \text { Flinders university and Flinders Medical } \\
\text { center, Bedford Park SA } 5042\end{array}$ \\
\hline $\begin{array}{l}\text { 7. Dr Wai Tat } \\
\text { WONG }\end{array}$ & wtwong@cuhk.edu.hk & & FCICM & $\begin{array}{l}\text { Clinical Professional Consultant } \\
11 . \quad \text { The Chinese University of Hong Kong }\end{array}$ \\
\hline $\begin{array}{l}\text { 8. Ms Navya } \\
\text { GULLAPALLI }\end{array}$ & navya.gullapalli@gmail.com & & $\begin{array}{l}\text { Medical } \\
\text { Student }\end{array}$ & $\begin{array}{l}\text { Final Year Medical Student } \\
\text { 12. } \quad \text { Monash University, Clayton VIC }\end{array}$ \\
\hline $\begin{array}{l}\text { 9. Dr Markus } \\
\text { RENNER }\end{array}$ & Markus.Renner@southerndhb.govt.nz & & EDIC, DDU & $\begin{array}{l}\text { Senior staff specialist } \\
13 . \quad \text { Dunedin Hospital, SDHB } \\
\text { 14. } \quad \text { Senior clinical lecturer Otago University, NZ. }\end{array}$ \\
\hline $\begin{array}{l}\text { 10. Dr Claudia } \\
\text { Maria } \\
\text { ALCANCIA }\end{array}$ & Claudia.Alcancia@gmail.com & & MD & $\begin{array}{l}\text { Clinical Fellow } \\
\text { 15. Makati Medical Center, Philippines } \\
\text { 16. Cardiothoracic Intensive Care Unit, National } \\
\text { University Hospital (Clinical fellow) }\end{array}$ \\
\hline $\begin{array}{l}\text { 11. Dr Kollengode } \\
\text { RAMANATHAN }\end{array}$ & Ram_ramanathan@nuhs.edu.sg & & FCICM & $\begin{array}{l}\text { Senior Consultant } \\
17 . \quad \text { National University Hospital, Singapore }\end{array}$ \\
\hline
\end{tabular}

\section{Corresponding author}

Dr Arvind Rajamani, $\mathrm{FClCM}$,

Senior Staff Specialist, Nepean Hospital, Kingswood, NSW 2747, Australia

PhD Student, University of Sydney, Nepean Clinical School, Kingswood, NSW 2747

Phone -+61247342000 
Email- rrarvind@hotmail.com

Funding - no funding received

Competing interests - No competing interests. 


\begin{tabular}{|c|c|c|c|c|c|c|}
\hline \multicolumn{7}{|c|}{ Author Contributorship } \\
\hline Author Name & $\begin{array}{l}\text { Study } \\
\text { Design }\end{array}$ & $\begin{array}{c}\text { Survey } \\
\text { Distribution }\end{array}$ & $\begin{array}{c}\text { Writing } \\
\text { Manuscript }\end{array}$ & $\begin{array}{l}\text { Finalization } \\
\text { of } \\
\text { Manuscript }\end{array}$ & $\begin{array}{c}\text { Tables } \\
\& \\
\text { Figures }\end{array}$ & $\begin{array}{l}\text { Critical } \\
\text { evaluation } \\
\text { of } \\
\text { manuscript }\end{array}$ \\
\hline $\begin{array}{l}\text { Arvind } \\
\text { Rajamani }\end{array}$ & Yes & Yes & Yes & Yes & Yes & Yes \\
\hline $\begin{array}{l}\text { Ashwin } \\
\text { Subramaniam }\end{array}$ & Yes & Yes & Yes & Yes & Yes & Yes \\
\hline Kiran Shekar & & Yes & Yes & & & Yes \\
\hline Jumana Haji & & Yes & Yes & & Yes & Yes \\
\hline Jinghang Luo & & & Yes & Yes & Yes & Yes \\
\hline $\begin{array}{l}\text { Shailesh } \\
\text { Bihari }\end{array}$ & & Yes & Yes & & & Yes \\
\hline Wai Tat Wong & & Yes & & & & Yes \\
\hline $\begin{array}{l}\text { Claudia Maria } \\
\text { Alcancia }\end{array}$ & & Yes & & & & Yes \\
\hline $\begin{array}{l}\text { Navya } \\
\text { Gullapalli }\end{array}$ & & & & & Yes & Yes \\
\hline $\begin{array}{l}\text { Markus } \\
\text { Renner }\end{array}$ & & Yes & & & & Yes \\
\hline $\begin{array}{l}\text { Kollengode } \\
\text { Ramanathan }\end{array}$ & Yes & Yes & Yes & Yes & Yes & Yes \\
\hline
\end{tabular}




\section{Summary Box}

What is already known on this topic

- Personal-protective equipment (PPE) is the cornerstone to preventing HCWinfections. A search was done on March 23, 2020 on PubMed, Embase or Google Scholar using the mesh terms "personal protective equipment", "PPE", “preparedness OR practice OR training". It revealed no previous studies on PPE preparedness in intensive care units (ICUs). No filters were used for the search.

- Several guidelines/recommendations issued by health organisations on PPE practice exist

What are the new findings

- As the first study to evaluate PPE-preparedness in ICUs, it demonstrated major concerns on PPE-preparedness across several ICUs, particularly in Australia, India and Philippines. There was suboptimal PPE-training, under-utilisation of low-cost interventions such as buddy-systems/team-training, and stock-awareness.

- The guidelines by health organisations on PPE practice have several conflicting recommendations.

How might it impact on clinical practice in the foreseeable future

- Standardising PPE guidelines by health organisations may translate to better training, better compliance and policies that improve HCW safety.

- To ensure the safety and well-being of HCWs, urgent measures are needed to improve PPE-preparedness and building systems with deeply embedded culture of safety. By helping ICUs evaluate and improve their current state of PPE preparedness, the study may help prevent healthcare worker infections and save lives. 
medRxiv preprint doi: https://doi.org/10.1101/2020.05.06.20093724; this version posted May 11, 2020. The copyright holder for this preprint (which was not certified by peer review) is the author/funder, who has granted medRxiv a license to display the preprint in perpetuity.

\section{Abstract (Word Count 276 words)}

Objectives: To evaluate PPE-preparedness across intensive care units (ICUs) in 6 Asia-Pacific countries. PPE-preparedness was defined as the adherence to guidelines, training HCWs, procuring PPE stocks and responding appropriately to a suspected case (transportation and admission to hospital).

Design: Cross-sectional web-based survey.

Setting: ICUs in Australia, New Zealand (NZ), Singapore, Hong Kong (HK), India and Philippines with a 24/7 Emergency/Casualty Department, and capable of mechanically ventilating patients for $>24$ hours.

Interventions: Questionnaire sent to intensivists in 633 Level II/III ICUs in 6 Asia-Pacific countries by email, WhatsApp ${ }^{\mathrm{TM}}$ and text messaging.

Main outcome measures: 263 intensivists responded, of whom 231 were eligible for analysis. Response rates were $68 \%-100 \%$ in all countries except India, where it was $24 \%$. 97\% either conformed to or exceeded WHO recommendations for PPE-practice. 59\% employed airborne precautions irrespective of aerosol-generation-procedures. There were variations in negative-pressure room use (highest in HK/Singapore), training (best in NZ), and PPE stock-awareness (best in HK/Singapore/NZ). High-flow-nasal-oxygenation and noninvasive ventilation were not options in most HK (66.7\%, 83.3\% respectively) and Singapore ICUs (50\%, 80\% respectively), but were considered in other countries to a greater extent. $38 \%$ reported not having specialized airway teams. Showering and "buddy-systems" were underutilized. Clinical waste disposal training was suboptimal (38\%).

Conclusions: Most intensivists from six Asia-Pacific countries appeared to be aware of the WHO PPE-guidelines by either conforming to/exceeding the recommendations. Despite this, there were widespread variabilities across ICUs and countries in several domains, particularly related to PPE-training and preparedness. Standardising PPE guidelines may translate to better training, better compliance and policies that improve HCW safety. Adopting low-cost approaches such as buddy-systems should be encouraged. More importantly, better pandemic preparedness and building systems with deeply embedded culture of safety is essential to ensure the safety and well-being of HCWs during such pandemics. 
medRxiv preprint doi: https://doi.org/10.1101/2020.05.06.20093724; this version posted May 11, 2020. The copyright holder for this preprint (which was not certified by peer review) is the author/funder, who has granted medRxiv a license to display the preprint in perpetuity.

All rights reserved. No reuse allowed without permission.

\section{Main Manuscript (Word count 2261 words) Introduction}

The Severe Acute Respiratory Syndrome-Coronavirus-2 (SARS-CoV-2) pandemic has caused an unprecedented rise in the number of hospital and intensive care unit (ICU) admissions worldwide. Between 5-32\% of coronavirus disease-2019 (COVID-19) patients may require critical care support.[1,2] Asia-Pacific countries are preparing for an anticipated surge in ICU admissions.[1,3,4] Due to its high transmissibility,[5] ICU healthcare workers (HCWs) are at particular risk of infection.[6]

Adequate preparedness with personal-protective equipment (PPE) is the cornerstone to preventing HCW-infections. [7,8] PPE-preparedness for pandemics was defined as the adherence to guidelines, training HCWs, procuring PPE stocks and responding appropriately to a suspected case (transportation and admission to hospital).[9] Suboptimal PPEpreparedness may cause PPE breaches, thereby exposing HCWs to SARS-CoV-2 infection.[10] Reports in India and Australia suggest a rising rate of HCW infections despite a low overall caseload,[11,12] raising concerns about the effectiveness of PPE practice and stocks. $[13,14]$ Moreover, there are conflicting recommendations from international, national, and regional organisations.[5,15] For example, the World Health Organisation (WHO) recommends a tiered approach of using droplet precautions for non-aerosolgenerating procedures (AGPS), and using airborne precautions only for AGPs. However, the Australia-New Zealand Intensive Care Society (ANZICS)[15] recommends that ICU-HCWs must routinely use airborne precautions, irrespective of the AGP-risk. HCW-infection rates vary between countries, $[16,17]$ with reports suggesting a lower incidence with advanced PPE measures and good PPE-practice bundles.[18-20]

While HCWs deserve the highest level of PPE-protection, inappropriate PPE usage driven by anxiety rather than clinical requirements, may deplete already scarce stocks. PPE availability must be accompanied by rigorous training systems in every ICU.[21-27] Since there is no literature on PPE-preparedness for the COVID-19 pandemic, we conducted a multinational cross-sectional survey of intensivists in 6 Asia-Pacific countries to comprehensively evaluate PPE-preparedness and compliance with WHO PPErecommendations. 
medRxiv preprint doi: https://doi.org/10.1101/2020.05.06.20093724; this version posted May 11, 2020. The copyright holder for this preprint (which was not certified by peer review) is the author/funder, who has granted medRxiv a license to display the preprint in perpetuity.

\section{Methods}

\section{Study Design}

Cross-sectional web-based survey of intensivists to evaluate PPE-preparedness in AsiaPacific ICUs. The survey remained open for completion between 25/03/2020 and 06/04/2020.

\section{Development of the survey}

Established standards and guidelines were utilized to design and validate the survey prior to dissemination. $[28,29]$ The broad research topic (PPE-preparedness in Asia-Pacific ICUs) and the questionnaire were developed after several rounds of consensus-building process between intensive care and infectious diseases specialists, based on data from the EuroNHID project.[7] Since it was a multinational survey, the WHO recommendations ${ }^{9}$ were chosen as the reference standard to evaluate PPE-preparedness in each country. After a process of item-generation and item-reduction, the questionnaire was piloted using 6 intensivists to evaluate completeness and clarity, and then administered to 12 intensivists from participating countries to assess its ability to discriminate among responses, ease of use and content validity (Table 1).

\section{Participant population and distribution of the survey}

Following ethical approval (approval number 2020/ETH00705) from local Human Research Ethics Committee, the survey weblink was distributed by email, text message and WhatsApp ${ }^{\mathrm{TM}}$ to qualified intensivists in Australia, New Zealand (NZ), Singapore, Hong Kong (HK), India and Philippines. The target participants were intensivists from hospitals with a 24/7 Emergency/Casualty Department, having an ICU capable of supporting mechanically ventilated patients for $>24$ hours. $[30,31]$ Two reminders were sent 3 days apart. One response per ICU was allowed. If multiple responses per site were received, the first response was chosen. Participation was voluntary, with no incentives offered, financial or otherwise.

\section{Results}

The survey was administered to 633 intensivists from Australia ( $n=99), N Z$ ( $n=14)$, HK $(n=13)$, Singapore $(n=6)$, India $(n=481)$ and Philippines $(n=20)$. The response rate was $100 \%$ in NZ and Singapore, 92.3\% in HK (12/13), 69\% (68/99) in Australia, 80\% in Philippines $(16 / 20)$ and $24 \%$ in India (115/481). Overall, 263/633 intensivists responded (42\%). After 
medRxiv preprint doi: https://doi.org/10.1101/2020.05.06.20093724; this version posted May 11, 2020. The copyright holder for this preprint (which was not certified by peer review) is the author/funder, who has granted medRxiv a license to display the preprint in perpetuity.

All rights reserved. No reuse allowed without permission.

exclusion of duplicates and responses from ineligible institutions, 231 (37\%) valid responses were included in the final analysis (CONSORT diagram, Figure 1). Except in Philippines, responses in each country had wide geographical spread across states/territories/regions. PPE-training (Table 2 and Table 3)

Regular team-training on tracheal intubation was provided in $79 \%$ NZ ICUs, $59 \%$ in Australia, 50\% in Singapore, and 19\%-33\% in the other countries. Overall, 66\% reported establishing special intubation teams of senior anaesthetists (4\%), senior intensivists (10\%), or a combination of both (52\%), ranging from 33\% in Singapore to $93 \%$ in NZ.

Regular training in donning/doffing was provided in all NZ ICUs, 79\% in Australia, 75\% in $\mathrm{HK}, 67 \%$ in Singapore, $62 \%$ in Philippines and $42 \%$ in India. Regular training for intra-hospital transport of COVID-19 patients ranged between $8 \%$ (HK) to 50\% (NZ). Regular training on waste disposal for ICU cleaners ranged between 33\% (HK/Singapore) and 56\% (Philippines). PPE Practice (i.e., choice of equipment) - Table 2, Figure 2 and sFigure 1

$224 / 231$ (97\%) either conformed to/exceeded the WHO recommendations. $3 \%$ did not report wearing masks. $38 \%$ conformed to the WHO recommendations of using medical masks for non-AGPs (“droplet precautions”) and limiting N95/P2 masks (i.e., airborne precautions) to AGPS alone. 59\% used airborne precautions routinely, irrespective of AGP risk (range $48 \%$ in Australia to $92 \%$ in HK) (Figure 2).

Only 6\% used personal-air-purifying-respirators (PAPR), except in Singapore where half the ICUs used PAPR for AGPs. 35\% ICUs used full body suits, with variations between countries - not used in NZ to $94 \%$ in Philippines.

sFigure 1 summarizes the use of head-covers/caps (71\%), shoe-covers (45\%), neckcovers (37\%), hospital scrubs (58\%) and impervious gowns (58\%). Showering/shampooing hair were routine practice in $60 \%$ ICUs, typically after the shift (46\%), and/or after PPE breach (15\%) (Table 1).

27\% ICUs performed N95/P2-mask fit-testing with quantitative/qualitative methods. There was wide inter-country variability, from $100 \%$ (HK, Singapore), $64 \%$ (NZ) to $11 \%-44 \%$ in the others.

Observers to monitor/checking on colleagues while donning/doffing PPE ("buddysystem")[32] was mandatory practice in 64\% in NZ ICUs, 51\% in Australia and 50\% in Singapore, and less common in other countries, ranging between 16\%-31\%. 
medRxiv preprint doi: https://doi.org/10.1101/2020.05.06.20093724; this version posted May 11, 2020. The copyright holder for this preprint (which was not certified by peer review) is the author/funder, who has granted medRxiv a license to display the preprint in perpetuity.

All rights reserved. No reuse allowed without permission.

Disposition of COVID-19 patients in the ICU and modes of oxygen-therapy for non-intubated patients

There were variations on where the different ICUs countries managed COVID-19 patients (Table 3). Respondents from 37\% ICUs (especially in HK and Singapore) stated using negative-pressure rooms exclusively. Overall, $58 \%$ were prepared to use non-negativepressure rooms if necessary (i.e. neutral-pressure single rooms, dedicated/cohorted COVID19 area). Only 1 respondent each from HK and Singapore reported using non-negativepressure rooms.

Low-flow oxygen-therapy, high-flow nasal oxygenation (HFNO) and non-invasive ventilation (NIV) were reported as "not an option in COVID-19 patients" by $14 \%, 26 \%$ and $45 \%$ respondents respectively, particularly in Singapore and HK, where $80 \%$ avoided NIV, and $50 \%$ and $67 \%$ avoided HFNO respectively (Figure 3). Other respondents were prepared to use low-flow oxygen (39\%), HFNO (45\%) and NIV (34\%) for patients in negative-pressure rooms or dedicated/cohorted areas.

\section{Other aspects}

Awareness of institutional PPE stocks being adequate to manage three COVID-19 patients for 1 week ranged from 41\% (Australia) to 92\% (HK) (Table 2).

Overall, $70 \%$ of respondents curbed family visits to the ICU (Table 2). Family communications were either by phone or videoconferencing. NZ, HK and Singapore ICUs all had reduced visiting rights, compared with $12-28 \%$ in other countries where policies were unchanged.

Overall, $28 \%$ of respondents reported feeling safe, many of them in NZ, Singapore and HK. $29 \%$ felt unsafe, and the remainder were neutral. Between $64 \%-83 \%$ of Singaporean, HK and NZ intensivists expressed confidence in their PPE-preparedness, while most intensivists in Australia, India and Philippines felt that their PPE-preparedness were suboptimal (sTable 2).

\section{Discussion}

\section{Statement of principal findings}

To our knowledge, this multinational survey is the first to systematically evaluate ICU PPE- preparedness for the COVID-19 pandemic. Although the overwhelming majority of ICUs conformed to the WHO recommendations for PPE-usage, there were marked variations in 
medRxiv preprint doi: https://doi.org/10.1101/2020.05.06.20093724; this version posted May 11, 2020. The copyright holder for this preprint (which was not certified by peer review) is the author/funder, who has granted medRxiv a license to display the preprint in perpetuity.

All rights reserved. No reuse allowed without permission.

the level of PPE-preparedness. ICUs in NZ, HK and Singapore appeared to have the most well-developed systems, training and/or practice compared to ICUs across Australia, India and Philippines, which had inconsistent systems. There were variations between countries in every aspect of PPE-preparedness namely, PPE-training, PPE stock-awareness, negativepressure room use, use of HFNO/NIV for non-intubated patients, "buddy-systems", teamtraining exercises and showering practices.

Variations in PPE-training

The most important and immediately remediable concern identified was the suboptimal training for ICU-HCWs, which may lead to suboptimal PPE-practice. Although regular training on PPE donning and doffing was offered in most ICUs, training for other aerosolgenerating activities was inconsistent in all countries, with NZ being better than the others. Such ICUs may aim to emulate the PPE-training reported by NZ respondents, and immediately initiate training sessions on N95/P2 mask fit-testing, donning/doffing PPE, AGPminimisation strategies, specialised intubation teams, transport, cleaning/waste disposal, and low-cost but effective mechanisms such as buddy-systems. These will improve safety and team-bonding. $[8,26,32]$

Disposition of COVID-19 patients in the ICU and Modes of Oxygen-Therapy for NonIntubated Patients

Compared to other countries, more intensivists from HK and Singapore reported that they would exclusively use negative-pressure rooms to manage COVID-19 patients. This may reflect the increased availability of such rooms in their ICUs, in turn demonstrating better pandemic-preparedness following the SARS-CoV-1 pandemic. Despite this, respondents from these 2 countries commonly avoided using HFNO and NIV, while intensivists in other countries used them more commonly. The use of HFNO and NIV in negative-pressure rooms or cohorted areas is recommended by several PPE guidelines, provided HCWs employ PPE with airborne-precautions.[15,33] Inappropriate avoidance of these therapies may result in unnecessary intubation or palliation of patients, hence needs reconsideration. Variations in PPE-practice across countries; Potential effects of conflicting PPErecommendations

The variations in ICU PPE-practice across the countries surveyed may partly be due to the startling multitude of international, national, regional, local/institutional and even departmental PPE guidelines, sometimes making contradictory recommendations (sTable 1). 
medRxiv preprint doi: https://doi.org/10.1101/2020.05.06.20093724; this version posted May 11, 2020. The copyright holder for this preprint (which was not certified by peer review) is the author/funder, who has granted medRxiv a license to display the preprint in perpetuity.

All rights reserved. No reuse allowed without permission.

For instance, when managing COVID-19 patients, one-third of respondents followed the WHO "Rational Use of PPE" recommendations[5] of reserving airborne precautions (i.e., N95/P2 masks) exclusively for AGPS, while 60\% were in line with the ANZICS recommendations of routinely using N95/P2 masks, irrespective of AGPs. There were variations between and within countries, with airborne precautions being more common in HK and Singapore. There is pre-COVID-19 evidence that routine airborne precautions may be more protective than targeted airborne-precautions.[19,20,34] However, the optimal strategy to strike a balance between conserving N95/P2 masks and ensuring ICU-HCW safety is unclear. Regardless, since conflicting PPE-recommendations have the potential to cause confusion and errors,[35] health administrators in a region/state/country must ensure a clear and consistent guideline across their jurisdiction to promote consistency in training/practice and build staff confidence. Health advisory organisations may attempt to unify their PPE recommendations to minimise practice-variation.

\section{Other aspects}

It is concerning that many intensivists were unaware of their PPE stock adequacy. This demands urgent attention. Administrators may consider implementing innovative solutions to keep track of each hospital's current and future PPE stock, as has been done in Australia/NZ.[36]

Our survey found that very few respondents reported using neck and shoe covers. Also, most PPE-guidelines do not incorporate these in their recommendations. As the soles of HCWs' shoes might function as carriers in spreading the virus, ICU-HCWs may consider stricter protective measures (e.g., caps, shoe and neck covers).[37]

Regarding family visitation, almost one-third of ICUs reported unchanged practices, which may potentially deplete PPE stocks, but also expose family members to infection.[37] As employed by NZ, HK and Singapore ICUs, phone or video-conferencing communication solutions may be suitable alternatives.

Finally, it was clear that good PPE-preparedness resulted in better perceptions of ICUHCW safety. More intensivists from ICUs with homogeneous PPE-practices (HK, Singapore and NZ) felt safer, compared to intensivists from the other countries.

Strengths and weaknesses

The strengths of this survey included a robust process to develop the questionnaire. Responses were limited to one intensivist/ICU; non-medical respondents were excluded to 
medRxiv preprint doi: https://doi.org/10.1101/2020.05.06.20093724; this version posted May 11, 2020. The copyright holder for this preprint (which was not certified by peer review) is the author/funder, who has granted medRxiv a license to display the preprint in perpetuity.

All rights reserved. No reuse allowed without permission.

keep the respondents homogeneous. Both well-resourced and less-resourced countries were included. Even in the midst of the COVID-19 pandemic, the response rate in all countries was high, except India, where responses were obtained widely from 23/27 states.

Our study has several limitations. Inherent to any survey, the submissions were selfdeclared statements without independent corroboration. Given the rapid evolution of PPEpreparedness, it is possible that the issues identified during the survey have already been addressed. The random selection of participants, coupled with the exclusion of non-medical HCWs, may induce reporting bias. The survey did not evaluate other AGPs like prone positioning, cardiac arrest, tracheostomy and bronchoscopies, partly due to unresolved ethical dilemmas (cardiac arrest) and partly to ensure feasibility of completion. The choice of the broad and pragmatic WHO guideline over ICU-specific guidelines (ANZICS) as the reference standard for ICU PPE practice is questionable but was done since it is more applicable to a multinational setting and does have a section on PPE for AGPs. Finally, despite the wide geographical spread of respondents, the low response rate in India and the small number of Philippines ICUs may limit the applicability of the results in those countries. Unanswered questions and future research

Although the link between PPE-preparedness and ICU-HCW infections is plausible, the association/causal link may be better evaluated using case-control or retrospective cohort studies to compare $\mathrm{HCW}$-infection rates between countries with variable training/practices. A follow-up survey may help evaluate any changes in PPE-practice/training in the ICUs that were surveyed.

Meaning of the study

The survey identified several deficiencies in PPE-preparedness across Asia-Pacific ICUs that demand the urgent attention of administrators and policymakers to institute corrective steps to ensure HCW safety.

\section{Conclusions}

The survey found that most intensivists from six Asia-Pacific countries showed good awareness of the WHO PPE-guidelines by either conforming to/exceeding the recommendations. Despite this, there were widespread variabilities across ICUs and countries in several domains, particularly related to PPE-training and preparedness. Standardising PPE guidelines may translate to better training, better compliance and policies 
medRxiv preprint doi: https://doi.org/10.1101/2020.05.06.20093724; this version posted May 11, 2020. The copyright holder for this preprint (which was not certified by peer review) is the author/funder, who has granted medRxiv a license to display the preprint in perpetuity.

All rights reserved. No reuse allowed without permission.

that improve HCW safety. Adopting low-cost approaches such as buddy-systems should be encouraged. More importantly, better pandemic preparedness and building systems with deeply embedded culture of safety is essential to ensure the safety and well-being of HCWs during such pandemics.

\section{Acknowledgements}

The authors thank Dr Adam Howard, Intensivist, Royal Perth Hospital, Western Australia, Dr Ross Freebairn, Intensivist, Hawkes Bay Hospital, New Zealand and Dr Paul Young, Wellington Hospital, New Zealand for their valuable inputs. Dr Shekar acknowledges research support from Metro North Hospital and Health Service. Dr Haji would like to acknowledge Dr. Prashant Kumar Editor 'Critical Care WA articles' HOD Critical Care, KHNI, Delhi - NCR for his help with the distribution of the survey in India.

\section{Competing interest (conflict of interest)}

All authors have completed the ICMJE uniform disclosure form at www.icmje.org/coi_disclosure.pdf and declare: no support from any organisation for the submitted work; no financial relationships with any organisations that might have an interest in the submitted work in the previous three years; no other relationships or activities that could appear to have influenced the submitted work. No funding received.

\section{Author Contributions}

\section{Listed in Title Page}

\section{Copyright/license for publication}

The Corresponding Author has the right to grant on behalf of all authors and does grant on behalf of all authors, a worldwide license to the Publishers and its licensees in perpetuity,

in all forms, formats and media (whether known now or created in the future), to i) publish, reproduce, distribute, display and store the Contribution, ii) translate the Contribution into other languages, create adaptations, reprints, include within collections and create summaries, extracts and/or, abstracts of the Contribution, iii) create any other derivative work(s) based on the Contribution, iv) to exploit all subsidiary rights in the Contribution, v) the inclusion of electronic links from the Contribution to third party material where-ever it may be located;

and, vi) license any third party to do any or all of the above. 
medRxiv preprint doi: https://doi.org/10.1101/2020.05.06.20093724; this version posted May 11, 2020. The copyright holder for this preprint (which was not certified by peer review) is the author/funder, who has granted medRxiv a license to display the preprint in perpetuity. All rights reserved. No reuse allowed without permission.

Transparency Declaration

The lead author and the manuscript's guarantor, Dr Arvind Rajamani, affirms that the manuscript is an honest, accurate, and transparent account of the study being reported; that no important aspects of the study have been omitted; and that any discrepancies from the study as originally planned (and, if relevant, registered) have been explained.

Funding source $-\mathrm{Nil}$

Patient and Public Involvement

Patients or the public WERE NOT involved in the design, or conduct, or reporting, or dissemination plans of our research 
medRxiv preprint doi: https://doi.org/10.1101/2020.05.06.20093724; this version posted May 11, 2020. The copyright holder for this preprint (which was not certified by peer review) is the author/funder, who has granted medRxiv a license to display the preprint in perpetuity.

All rights reserved. No reuse allowed without permission.

\section{References}

1. Yang $X, Y u Y, X u J$, et al. Clinical course and outcomes of critically ill patients with SARS-CoV-2 pneumonia in Wuhan, China: a single-centered, retrospective, observational study. Lancet Respir Med 2020 doi: 10.1016/S2213-2600(20)30079-5 [published Online First: 2020/02/28]

2. Cascella M, Rajnik M, Cuomo A, et al. Features, Evaluation and Treatment Coronavirus (COVID-19). StatPearls. Treasure Island (FL)2020.

3. Coronavirus (COVID-19) at a glance Australian Government Department of Health; [updated April 5. Available from:

https://www.health.gov.au/sites/default/files/documents/2020/04/coronavirus-covid-19at-a-glance-coronavirus-covid-19-at-a-glance-infographic 0.pdf accessed April 52020.

4. Sun D, Li H, Lu XX, et al. Clinical features of severe pediatric patients with coronavirus disease 2019 in Wuhan: a single center's observational study. World J Pediatr 2020 doi: 10.1007/s12519-020-00354-4 [published Online First: 2020/03/21]

5. World Health O. Rational use of personal protective equipment for coronavirus disease (COVID19): interim guidance, 27 February 2020. Geneva: World Health Organization, 2020.

6. Ong SWX, Tan YK, Chia PY, et al. Air, Surface Environmental, and Personal Protective Equipment Contamination by Severe Acute Respiratory Syndrome Coronavirus 2 (SARS-CoV-2) From a Symptomatic Patient. JAMA 2020 doi: 10.1001/jama.2020.3227

7. De laco G, Puro V, Fusco FM, et al. Personal protective equipment management and policies: European Network for Highly Infectious Diseases data from 48 isolation facilities in 16 European countries. Infect Control Hosp Epidemiol 2012;33(10):1008-16. doi: 10.1086/667729 [published Online First: 2012/09/11]

8. Phua J, Weng L, Ling L, et al. Intensive care management of coronavirus disease 2019 (COVID-19): challenges and recommendations. Lancet Respir Med 2020 doi: 10.1016/S22132600(20)30161-2 [published Online First: 2020/04/10]

9. Suijkerbuijk AWM, Swaan CM, Mangen MJ, et al. Ebola in the Netherlands, 2014-2015: costs of preparedness and response. The European journal of health economics : HEPAC : health economics in prevention and care 2018;19(7):935-43. doi: 10.1007/s10198-017-0940-4 [published Online First: 2017/11/18]

10. Schwartz J KC, Yen M. Protecting Health Care Workers during the COVID-19 Coronavirus Outbreak -Lessons from Taiwan's SARS response. Clinical Infectious Diseases 2020 doi: $10.1093 /$ cid/ciaa255

11. Debroy S. 10 per cent cases linked to hospital infections in Mumbai, point to lack of stringent protocols. Mumbai, India: Times of India; 2020 [updated April 10 2020. Available from: https://timesofindia.indiatimes.com/city/mumbai/10-per-cent-cases-linked-to-hospitalinfections-in-mumbai-point-to-lack-of-stringent-protocols/articleshow $/ 75074916 . \mathrm{cms}$ accessed April 10, 20202020.

12. Two hospitals closed in Tasmania as Australia's coronavirus deaths reach 59 SBS News; 2020 [updated April 12 2020. Available from: https://www.sbs.com.au/news/two-hospitalsclosed-in-tasmania-as-australia-s-coronavirus-deaths-reach-59 accessed April 122020.

13. Rimmer A. Covid-19: Third of surgeons do not have adequate PPE, royal college warns. BMJ 2020;369:m1492. doi: 10.1136/bmj.m1492

14. Sayburn A. Are UK doctors getting sufficient protective equipment against covid-19? BMJ 2020;369:m1297. doi: 10.1136/bmj.m1297

15. ANZICS COVID-19 Guidelines) Melbourne: : Australian and New Zealand Intensive Care Society (ANZICS); 2020 [1:[Available from: https://www.anzics.com.au/wpcontent/uploads/2020/03/ANZICS-COVID-19-Guidelines-Version-1.pdf accessed March 31 20202020. 
medRxiv preprint doi: https://doi.org/10.1101/2020.05.06.20093724; this version posted May 11, 2020. The copyright holder for this preprint (which was not certified by peer review) is the author/funder, who has granted medRxiv a license to display the preprint in perpetuity. All rights reserved. No reuse allowed without permission.

16. Integrated surveillance of COVID-19 in Italy: The COVID-19 Task force of the Department of Infectious Diseases and the IT Service Istituto Superiore di Sanità 2020 [updated 20 March 2020. accessed 31 March 2020.

17. Wang J ZM, Liu F. Reasons for healthcare workers becoming infected with novel coronavirus disease 2019 (COVID-19) in China. J Hosp Infect 2020 doi: 10.1016/j.jhin.2020.03.002 [published Online First: Mar 6.]

18. Schwartz J, King C-C, Yen M-Y. Protecting Healthcare Workers During the Coronavirus Disease 2019 (COVID-19) Outbreak: Lessons From Taiwan's Severe Acute Respiratory Syndrome Response. Clinical Infectious Diseases 2020 doi: 10.1093/cid/ciaa255

19. Huh S. How to train the health personnel for protecting themselves from novel coronavirus (COVID-19) infection during their patient or suspected case care. J Educ Eval Health Prof 2020;17:10. doi: 10.3352/jeehp.2020.17.10 [published Online First: 2020/03/11]

20. S R. Coronavirus: The Italian COVID-19 hospital where no medics have been infected: Sky News; 2020 [Available from: https://news.sky.com/story/coronavirus-the-italian-covid-19-hospitalwhere-no-medics-have-been-infected-11966344 accessed April 92020.

21. Al-Tawfiq JA, Rothwell S, McGregor HA, et al. A multi-faceted approach of a nursing led education in response to MERS-CoV infection. J Infect Public Health 2018;11(2):260-64. doi: 10.1016/j.jiph.2017.08.006 [published Online First: 2017/09/05]

22. Powers $D$, Armellino $D$, Dolansky $M$, et al. Factors influencing nurse compliance with Standard Precautions. Am J Infect Contro/ 2016;44(1):4-7. doi: 10.1016/j.ajic.2015.10.001 [published Online First: 2016/01/16]

23. Kang J, O'Donnell JM, Colaianne B, et al. Use of personal protective equipment among health care personnel: Results of clinical observations and simulations. Am J Infect Control 2017;45(1):17-23. doi: 10.1016/j.ajic.2016.08.011 [published Online First: 2017/01/10]

24. Gershon RR, Vandelinde N, Magda LA, et al. Evaluation of a pandemic preparedness training intervention of emergency medical services personnel. Prehosp Disaster Med 2009;24(6):508-11. doi: 10.1017/s1049023x00007421 [published Online First: 2010/03/20]

25. Fogel I, David O, Balik CH, et al. The association between self-perceived proficiency of personal protective equipment and objective performance: An observational study during a bioterrorism simulation drill. Am J Infect Control 2017;45(11):1238-42. doi: 10.1016/j.ajic.2017.05.018 [published Online First: 2017/07/05]

26. Fischer WA, 2nd, Weber D, Wohl DA. Personal Protective Equipment: Protecting Health Care Providers in an Ebola Outbreak. Clin Ther 2015;37(11):2402-10. doi: 10.1016/j.clinthera.2015.07.007 [published Online First: 2015/10/11]

27. Casalino E, Astocondor E, Sanchez JC, et al. Personal protective equipment for the Ebola virus disease: A comparison of 2 training programs. Am J Infect Control 2015;43(12):1281-7. doi: 10.1016/j.ajic.2015.07.007 [published Online First: 2015/08/19]

28. Dawson B, Trapp RG. Chapter 11. Survey Research. Basic \& Clinical Biostatistics, 4e. New York, NY: The McGraw-Hill Companies 2004.

29. Rajamani A, Miu M, Huang S, et al. Impact of Critical Care Point-of-Care Ultrasound ShortCourses on Trainee Competence. Critical care medicine 2019;47(9):e782-e84. doi: 10.1097/ccm.0000000000003867 [published Online First: 2019/06/05]

30. Minimum Standards For Intensive Care Units College of Intensive Care Medicine; [updated 2011 Available from: https://www.cicm.org.au/CICM Media/CICMSite/CICMWebsite/Resources/Professional\%20Documents/IC-1-Minimum-Standards-for-IntensiveCare-Units.pdf accessed April 12020.

31. Accredited Intensive Care Units Australia: College of Intensive Care Medicine; 2020 [Available from: https://cicm.org.au/Hospitals/Accredited-Sites-Accordion/Accredited-Units accessed March 312020. 
medRxiv preprint doi: https://doi.org/10.1101/2020.05.06.20093724; this version posted May 11, 2020. The copyright holder for this preprint

(which was not certified by peer review) is the author/funder, who has granted medRxiv a license to display the preprint in perpetuity.

All rights reserved. No reuse allowed without permission.

32. Chen $\mathrm{X}$, Tian J, Li G, et al. Initiation of a new infection control system for the COVID-19 outbreak. Lancet Infect Dis 2020;20(4):397-98. doi: 10.1016/S1473-3099(20)30110-9 [published Online First: 2020/02/23]

33. Zuo MZ HY, Ma WH, Xue ZG, Zhang JQ, Gong YH, Che L. Chinese Society of Anesthesiology Task Force on Airway Management: Expert recommendations for tracheal intubation in critically ill patients with novel coronavirus disease 2019. Chin Med Sci I 2020 doi: 10.24920/003724 [published Online First: Feb 27 2020]

34. Maclntyre CR, Chughtai AA, Rahman B, et al. The efficacy of medical masks and respirators against respiratory infection in healthcare workers. Influenza and other respiratory viruses 2017;11(6):511-17. doi: 10.1111/irv.12474 [published Online First: 2017/08/12]

35. McClymont K CR. Equipment bungle puts three St Vincent's Hospital staff in home isolation Sydney, Australia: Fairfax Media; 2020 [Available from:

https://www.smh.com.au/national/nsw/equipment-bungle-puts-three-st-vincent-s-hospitalstaff-in-home-isolation-20200414-p54jk9.html accessed April 132020.

36. CHRIS - Australia and New Zealand Critical Health Resource Information System 2020 [Available from: https://chris.health.gov.au/\#/portal/home accessed April 122020.

37. Guo ZD, Wang ZY, Zhang SF, et al. Aerosol and Surface Distribution of Severe Acute Respiratory Syndrome Coronavirus 2 in Hospital Wards, Wuhan, China, 2020. Emerging infectious diseases 2020;26(7) doi: 10.3201/eid2607.200885 [published Online First: 2020/04/11] 


\section{Figure Legends}

\begin{tabular}{|l|l|}
\hline Figure & \multicolumn{1}{|c|}{ Legend } \\
\hline Figure & $\begin{array}{l}\text { CONSORT diagram demonstrating 42\% response rate. After exclusion, 231 ICUs were } \\
\text { included for final analysis. Overall response rate was very good, except in India, which } \\
\text { reduced the overall response rate. } \\
\text { Key: ICU - intensive care unit }\end{array}$ \\
\hline $\begin{array}{l}\text { Figure } \\
2\end{array}$ & $\begin{array}{l}\text { Figure 2a shows respiratory PPE practices reported by intensivists in the different } \\
\text { countries. } \\
\text { Figure 2b shows how this reported use conformed to the WHO guidelines. } \\
\text { Key: } \\
\text { PAPR - personal air-purifying respirators } \\
\text { N95 - N9 mask } \\
\text { WHO - World Health Organisation }\end{array}$ \\
\hline Figure & $\begin{array}{l}\text { Disposition and management of a non-intubated COVID-19 patient } \\
\text { Key: } \\
\text { COVID-19 - coronavirus disease 2019 }\end{array}$ \\
\hline
\end{tabular}


Low Flow

Nasal

Oxygenation

Therapy as an option

High F
Nasal
Oxyge

Oxygenation

Therapy as

an option

Noninvasive
Therapy as an option

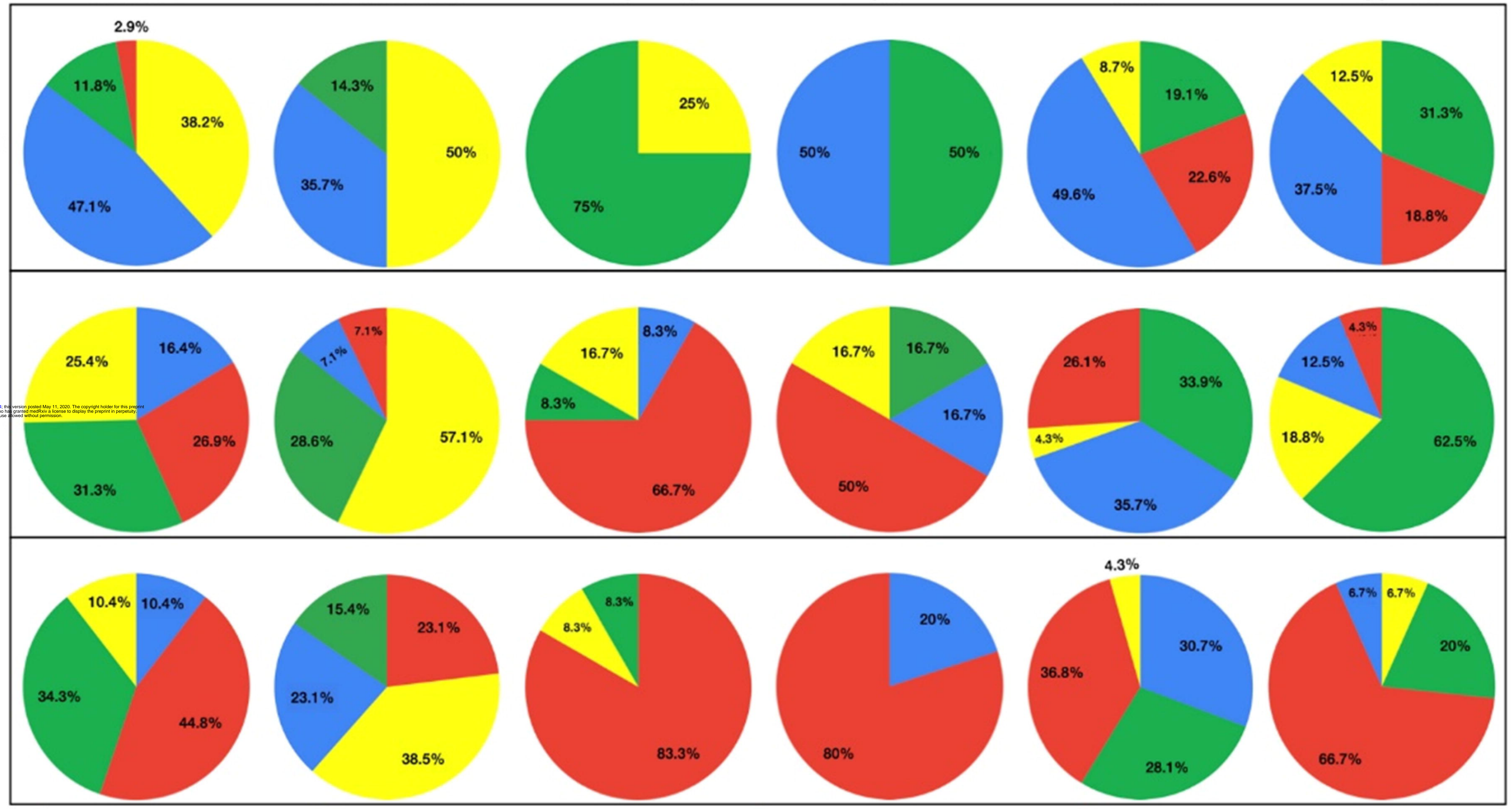

Negative pressure room $\bigcirc$ Negative pressure rooms with overflow $\bigcirc$ Neutral rooms with overflow $\bigcirc$ Not an option 


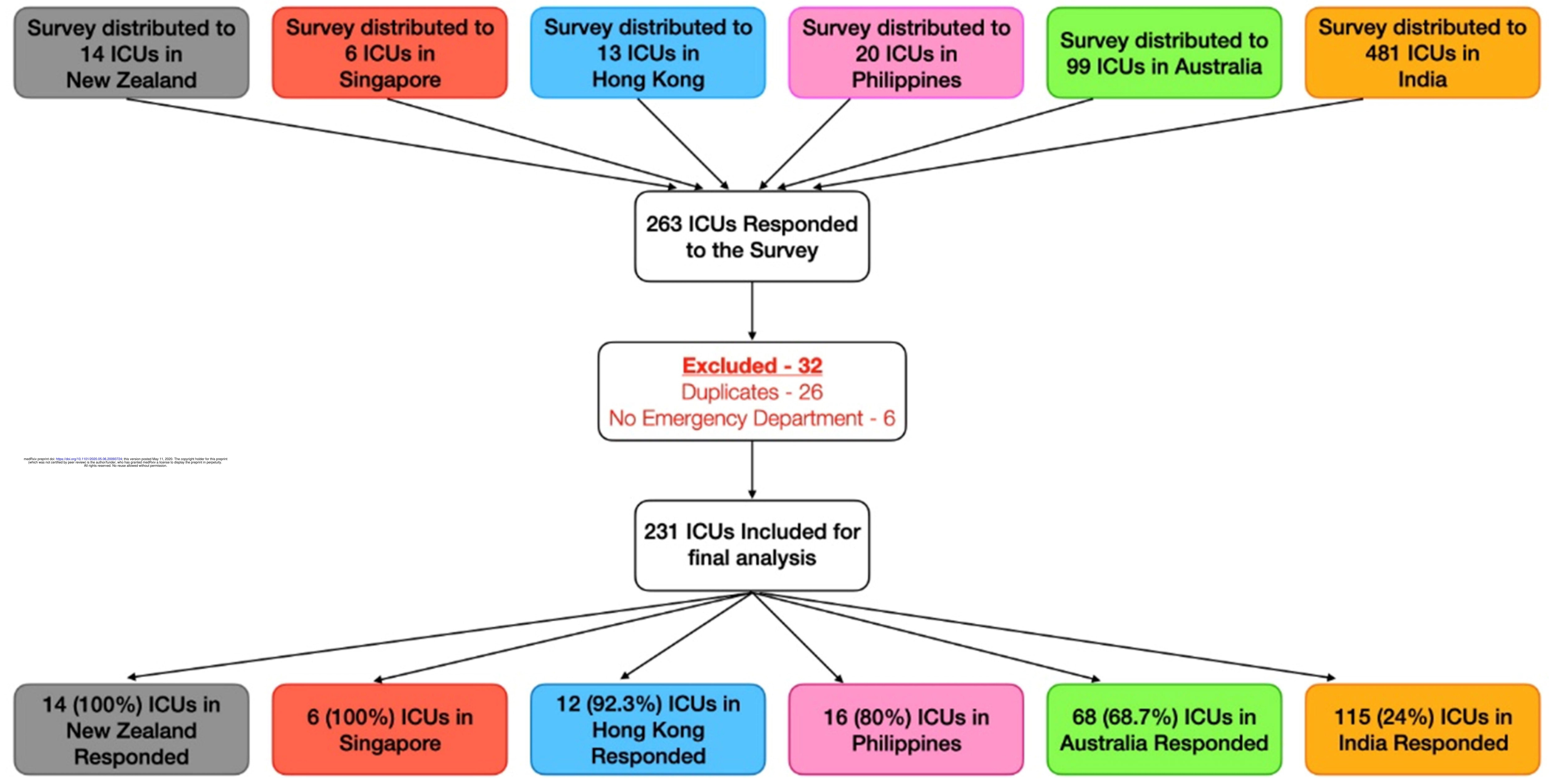




\section{$2 a$}

Philippines

$$
6.3 \%
$$

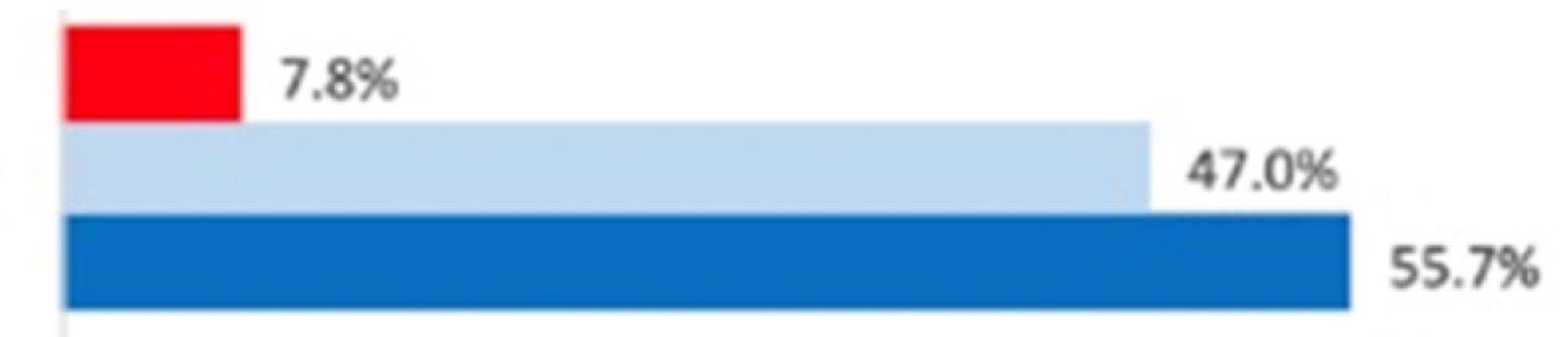

Singapore

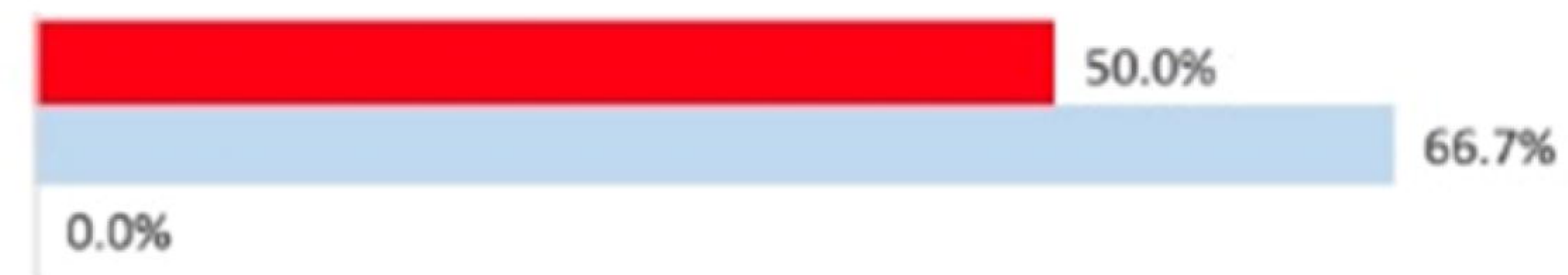

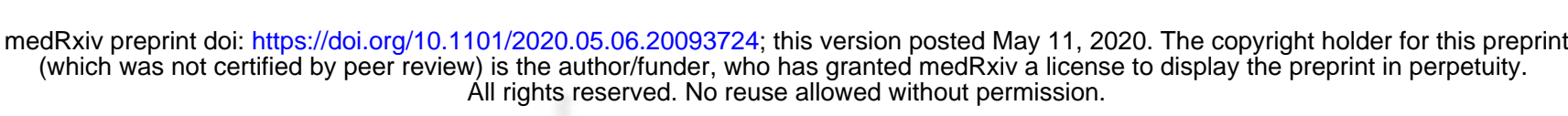

Hong Kong

$0.0 \%$

$0.0 \%$

$91.7 \%$

$0.1 \%$

\begin{tabular}{l|l} 
New Zealand & $3.6 \%$ \\
& $0.4 \%$
\end{tabular}

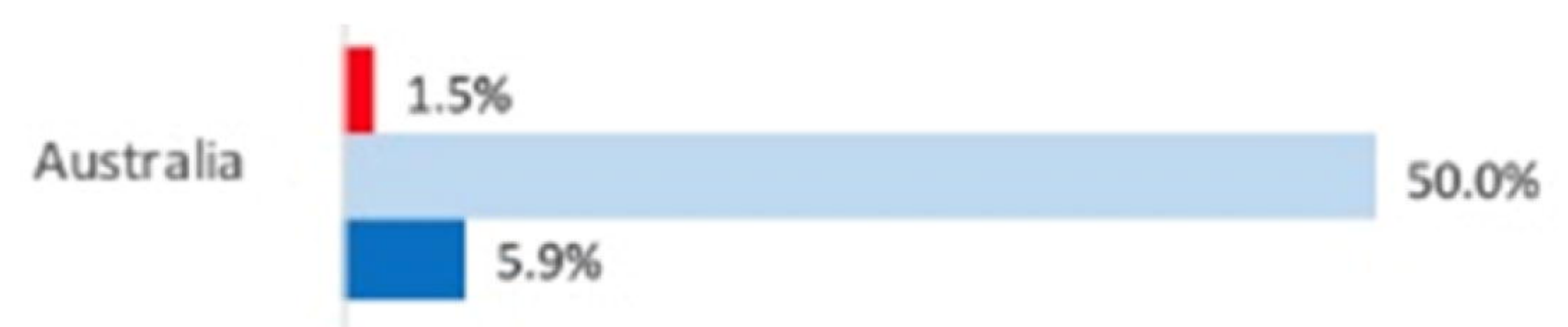

$0 \%$

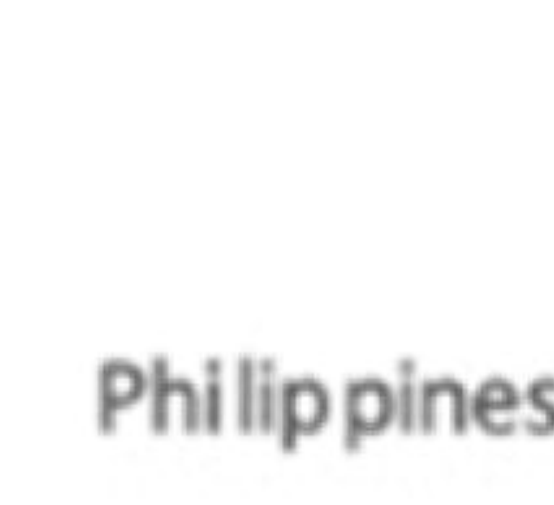

$0.0 \%$

Philippines

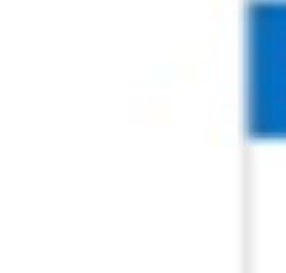
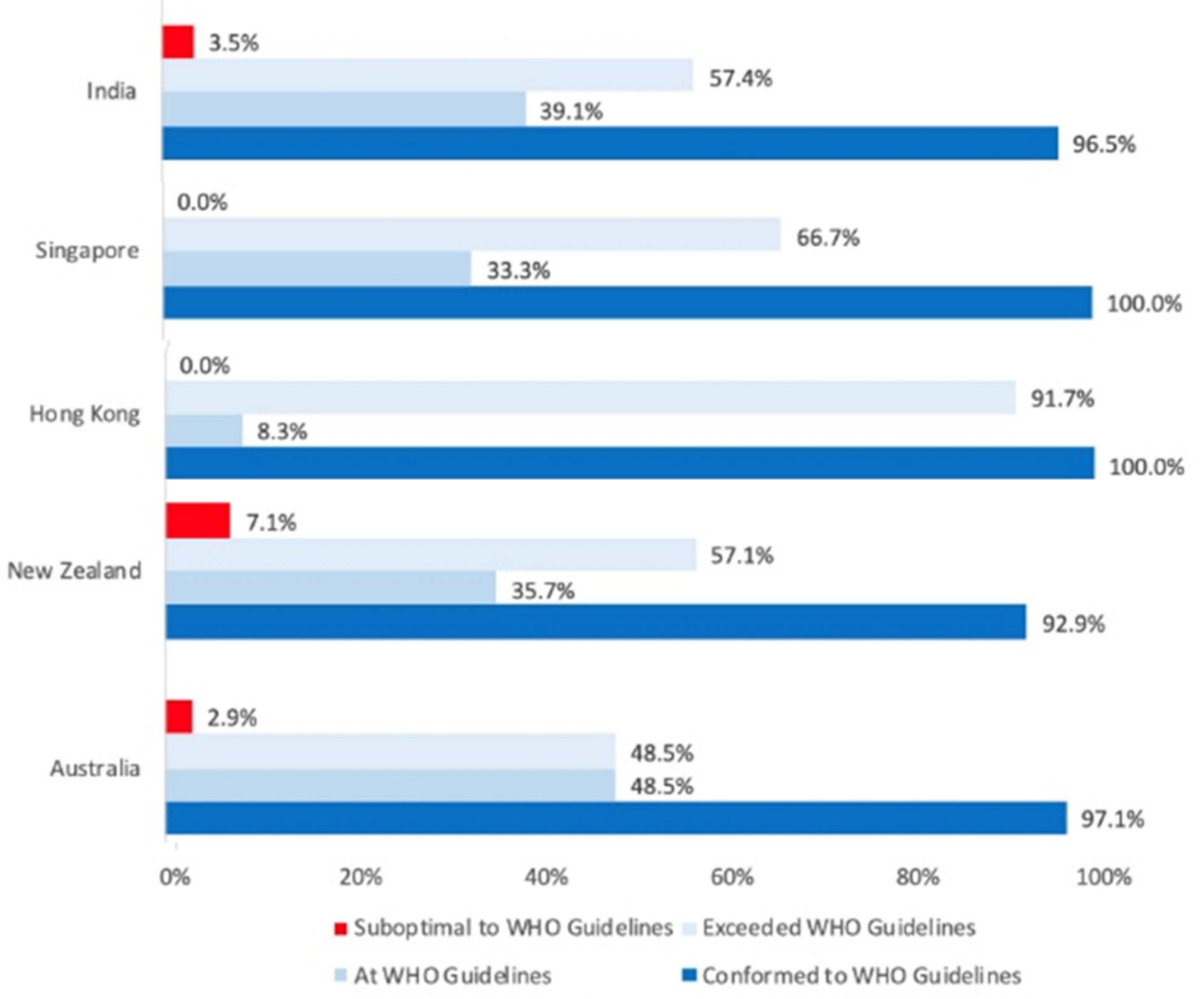


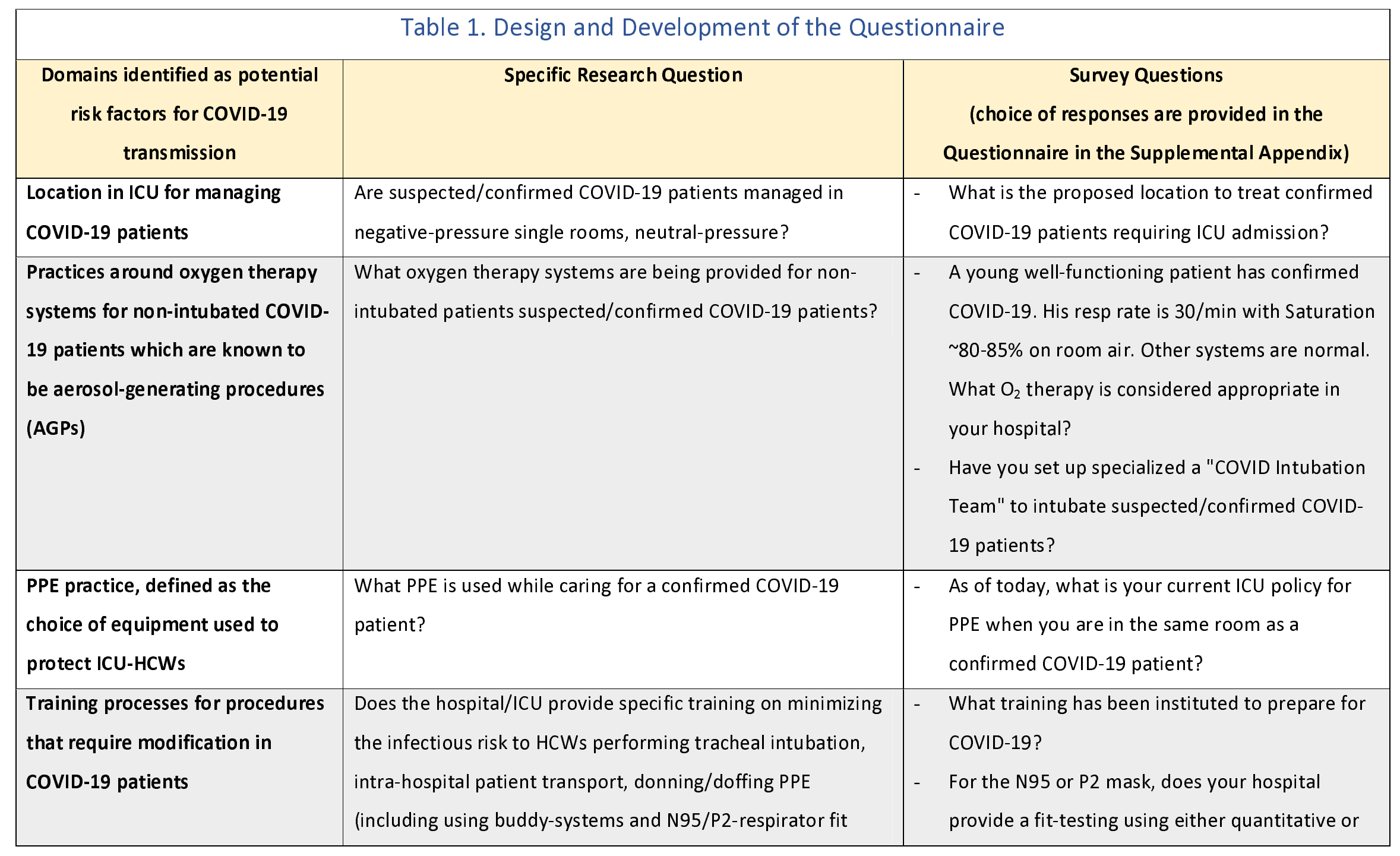




\begin{tabular}{|c|c|c|}
\hline & testing), and waste disposal? & $\begin{array}{l}\text { qualitative (odor-detection) methods? } \\
\text { - Do you have a "buddy-system" to check PPE } \\
\text { practice? } \\
\text { - Showering / shampooing after caring for a COVID } \\
\text { patient }\end{array}$ \\
\hline $\begin{array}{l}\text { PPE availability in each ICU (PPE- } \\
\text { stock) }\end{array}$ & Is the hospital/ICU aware of PPE stock? & $\begin{array}{l}\text { - Is the current stock of essential PPE equipment } \\
\text { adequate to manage } 3 \text { confirmed COVID-19 } \\
\text { patients in your ICU for at least } 1 \text { week? }\end{array}$ \\
\hline Ancillary domains of interest & $\begin{array}{l}\text { Does the hospital/ICU have a strategy on family visitation } \\
\text { practices, both to minimize unnecessary exposure of staff, } \\
\text { other patients and other relatives / families, and to optimize } \\
\text { PPE stock? } \\
\text { What is the overall perception of HCWs perceptions regarding } \\
\text { the PPE practice in their hospital/ICU? }\end{array}$ & $\begin{array}{l}\text { What family visitation / communication } \\
\text { strategies have you decided for COVID-19 } \\
\text { patients? } \\
\text { - Please describe what constitutes a "breach in } \\
\text { PPE" in your hospital. What measures do you } \\
\text { take when a breach is identified? } \\
\text { - Do you feel safe/secure and adequately } \\
\text { protected with the PPE methods offered by your } \\
\text { hospital/ICU? }\end{array}$ \\
\hline \multicolumn{3}{|c|}{$\begin{array}{l}\text { COVID-19 - Coronavirus disease of 2019, AGP - aerosol generating procedure, PPE - personal protective equipment, PAPR - powered air-purifying } \\
\text { respirator, N95 - not-resistant to oil-based aerosols, FFP2 - filtering facepiece-2 }\end{array}$} \\
\hline
\end{tabular}


Table 2: Key management strategies for Suspected/Confirmed COVID-19 patient

\begin{tabular}{|c|c|c|c|c|c|c|}
\hline & Australia & Hong Kong & India & New Zealand & Philippines & Singapore \\
\hline \multicolumn{7}{|c|}{ PPE safety measures of Asia-Pacific ICUs who conformed to WHO recommendations (also refer to Figure 2) } \\
\hline Conformed to WHO recommendations & $66(97.1 \%)$ & $12(100 \%)$ & $111(96.5 \%)$ & $13(92.9 \%)$ & $16(100 \%)$ & $6(100 \%)$ \\
\hline At the level of WHO recommendations & $33(48.5 \%)$ & $1(8.3 \%)$ & $45(39.1 \%)$ & $5(35.7 \%)$ & $2(12.5 \%)$ & $2(33.3 \%)$ \\
\hline Beyond WHO recommendations & $33(48.5 \%)$ & $11(91.7 \%)$ & $66(57.4 \%)$ & $8(57.1 \%)$ & $14(87.5 \%)$ & $4(66.7 \%)$ \\
\hline Suboptimal to WHO recommendations & $2(2.9 \%)$ & $0(0)$ & $4(3.5 \%)$ & $1(7.1 \%)$ & $0(0)$ & $0(0)$ \\
\hline \multicolumn{7}{|c|}{ Proposed location to treat confirmed COVID patients requiring ICU Admission } \\
\hline Negative pressure rooms only & $8(11.8 \%)$ & $11(91.7 \%)$ & $55(47.8 \%)$ & $2(14.3 \%)$ & $13(81.3 \%)$ & $5(83.3 \%)$ \\
\hline Negative pressure rooms where possible & $48(70.6 \%)$ & $1(8.3 \%)$ & $21(18.3 \%)$ & $12(85.7 \%)$ & $1(6.3 \%)$ & $1(16.7 \%)$ \\
\hline Neutral pressure rooms where possible & $7(10.3 \%)$ & $0(0.0 \%)$ & $8(7.0 \%)$ & $0(0.0 \%)$ & $0(0.0 \%)$ & $0(0.0 \%)$ \\
\hline Cohorted in a COVID ICU & $5(7.4 \%)$ & $0(0.0 \%)$ & $31(27.0 \%)$ & $0(0.0 \%)$ & $2(12.5 \%)$ & $0(0.0 \%)$ \\
\hline \multicolumn{7}{|c|}{ Specialized a "COVID Intubation Team" to intubate suspected/confirmed COVID patients } \\
\hline Anesthetists \& Intensivists & $43(63.2 \%)$ & $0(0)$ & $53(46.1 \%)$ & $11(78.6 \%)$ & $11(68.8 \%)$ & $2(33.3 \%)$ \\
\hline Senior Anesthetists & $7(10.3 \%)$ & $2(16.7 \%)$ & $0(0)$ & $0(0)$ & $0(0)$ & $0(0)$ \\
\hline Senior Intensivist & $2(2.9 \%)$ & $3(25.0 \%)$ & $16(13.9 \%)$ & $2(14.3 \%)$ & $0(0)$ & $0(0)$ \\
\hline No Specialised COVID Team & $16(23.5 \%)$ & $7(58.3 \%)$ & $46(40.0 \%)$ & $1(7.1 \%)$ & $5(31.3 \%)$ & $4(66.7 \%)$ \\
\hline \multicolumn{7}{|l|}{ Low-Cost Measures to Ensure PPE Safety } \\
\hline N95/P2 mask fit-testing & $16(23.5 \%)$ & $12(100.0 \%)$ & $13(11.3 \%)$ & $9(64.3 \%)$ & $7(43.8 \%)$ & $6(100.0 \%)$ \\
\hline \multicolumn{7}{|l|}{ "Buddy-system" to check PPE practice } \\
\hline Mandatory use of a "buddy" & $35(51.5 \%)$ & $2(16.7 \%)$ & $32(27.8 \%)$ & $9(64.3 \%)$ & $5(31.3 \%)$ & $3(50.0 \%)$ \\
\hline Ad Hoc use of a "buddy" & $31(45.6 \%)$ & $10(83.3 \%)$ & $79(68.7 \%)$ & $5(35.7 \%)$ & $11(68.8 \%)$ & $3(50.0 \%)$ \\
\hline No "buddy-system" adopted & $2(2.9 \%)$ & $0(0)$ & $4(3.5 \%)$ & $0(0)$ & $0(0)$ & $0(0)$ \\
\hline
\end{tabular}




\begin{tabular}{|c|c|c|c|c|c|c|}
\hline & Australia & Hong Kong & India & New Zealand & Philippines & Singapore \\
\hline \multicolumn{7}{|l|}{ Showering / Shampooing after caring for a COVID-19 patient } \\
\hline End of shift & $16(23.5 \%)$ & $1(8.3 \%)$ & $59(51.3 \%)$ & $9(64.3 \%)$ & $10(62.4 \%)$ & $2(33.3 \%)$ \\
\hline If PPE Breach & $10(14.7 \%)$ & $2(16.7 \%)$ & $3(2.6 \%)$ & $1(7.1 \%)$ & $0(0)$ & $0(0)$ \\
\hline Immediate (if PPE breach or AGP) & $2(2.9 \%)$ & $5(41.7 \%)$ & $12(10.4 \%)$ & $1(7.1 \%)$ & $3(18.6 \%)$ & $2(33.3 \%)$ \\
\hline Limited bathrooms & $3(4.4 \%)$ & $0(0)$ & $3(2.6 \%)$ & $1(7.1 \%)$ & $0(0)$ & $0(33.3 \%)$ \\
\hline No advice given & $37(54.4 \%)$ & $4(33.3 \%)$ & $37(32.2 \%)$ & $2(14.3 \%)$ & $3(18.8 \%)$ & $2(33.3 \%)$ \\
\hline \multicolumn{7}{|c|}{ Awareness of adequacy of current stock of essential PPE equipment to manage 3 confirmed COVID patients in your ICU for at least 1 week } \\
\hline \multicolumn{7}{|l|}{ Aware of PPE stock } \\
\hline Yes, available to care of 3 COVIDs for 1 week & $36(52.9 \%)$ & $11(91.7 \%)$ & $49(42.6 \%)$ & $12(85.7 \%)$ & $7(43.8 \%)$ & $5(83.3 \%)$ \\
\hline Not available to care of 3 COVIDs for 1 week & $12(17.6 \%)$ & $1(8.3 \%)$ & $34(29.6 \%)$ & $1(7.1 \%)$ & $3(18.8 \%)$ & $1(16.7 \%)$ \\
\hline Not aware of stock & $20(29.4 \%)$ & $0(0)$ & $32(27.8 \%)$ & $1(7.1 \%)$ & $6(37.5 \%)$ & $0(0)$ \\
\hline \multicolumn{7}{|l|}{ Family / NOK Visitation rights } \\
\hline Limited, in person & $21(30.9 \%)$ & $0(0.0 \%)$ & $9(7.8 \%)$ & $1(7.1 \%)$ & $0(0.0 \%)$ & $0(0.0 \%)$ \\
\hline Remotely with no exceptions & $36(52.9 \%)$ & $11(91.7 \%)$ & $74(64.3 \%)$ & $13(92.9 \%)$ & $13(81.3 \%)$ & $5(83.3 \%)$ \\
\hline Remotely, except at end of life & $3(4.4 \%)$ & $1(8.3 \%)$ & $0(0.0 \%)$ & $0(0.0 \%)$ & $0(0.0 \%)$ & $0(0.0 \%)$ \\
\hline Unchanged & $8(11.8 \%)$ & $0(0.0 \%)$ & $32(27.8 \%)$ & $0(0.0 \%)$ & $3(18.8 \%)$ & $1(16.7 \%)$ \\
\hline
\end{tabular}


medRxiv preprint doi: https://doi.org/10.1101/2020.05.06.20093724; this version posted May 11, 2020. The copyright holder for this preprint (which was not certified by peer review) is the author/funder, who has granted medRxiv a license to display the preprint in perpetuity.

All rights reserved. No reuse allowed without permission.

Table 3. Training processes for Activities Carrying High-Risk of Aerosol-

\section{Generation}

\begin{tabular}{|c|c|c|c|}
\hline & Daily or frequently & Not aware or not done & Occasional \\
\hline \multicolumn{4}{|c|}{ Intubating COVID-19 patients } \\
\hline Australia & $40(58.8)$ & $9(13.2)$ & $19(27.9)$ \\
\hline Hong Kong & $4(33.3)$ & $0(0)$ & $8(66.7)$ \\
\hline India & $21(18.3)$ & $52(45.2)$ & $42(36.5)$ \\
\hline New Zealand & $11(78.6)$ & $0(0)$ & $3(21.4)$ \\
\hline Philippines & $4(25.0)$ & $6(37.5)$ & $6(37.5)$ \\
\hline Singapore & $3(50.0)$ & $0(0)$ & $3(50.0)$ \\
\hline \multicolumn{4}{|c|}{ Transporting COVID-19 patients } \\
\hline Australia & $15(22.1)$ & $26(38.2)$ & $27(39.7)$ \\
\hline Hong Kong & $1(8.3)$ & $10(83.3)$ & $1(8.3)$ \\
\hline India & $19(16.5)$ & $60(52.2)$ & $36(31.3)$ \\
\hline New Zealand & $7(50.0)$ & $2(14.3)$ & $5(35.7)$ \\
\hline Philippines & $4(25.0)$ & $5(31.3)$ & $7(43.8)$ \\
\hline Singapore & $1(16.7)$ & $1(16.7)$ & $4(66.7)$ \\
\hline \multicolumn{4}{|c|}{ PPE donning and doffing } \\
\hline Australia & $54(79.4)$ & $1(1.5)$ & $13(19.1)$ \\
\hline Hong Kong & $9(75.0)$ & $0(0)$ & $3(25.0)$ \\
\hline India & $48(41.7)$ & $22(19.1)$ & $45(39.1)$ \\
\hline New Zealand & $14(100.0)$ & $0(0)$ & $0(0)$ \\
\hline Philippines & $10(62.5)$ & $1(6.3)$ & $5(31.3)$ \\
\hline Singapore & $4(66.7)$ & $0(0)$ & $2(33.3)$ \\
\hline \multicolumn{4}{|c|}{ PPE waste disposal for cleaners } \\
\hline Australia & $25(36.8)$ & $23(33.8)$ & $20(29.4)$ \\
\hline Hong Kong & $4(33.3)$ & $5(41.7)$ & $3(25.0)$ \\
\hline India & $43(37.4)$ & $36(31.3)$ & $36(31.3)$ \\
\hline New Zealand & $6(42.9)$ & $5(35.7)$ & $3(21.4)$ \\
\hline Philippines & $9(56.3)$ & $3(18.8)$ & $4(25.0)$ \\
\hline Singapore & $2(33.3)$ & $0(0)$ & $4(66.7)$ \\
\hline \multicolumn{4}{|c|}{ COVID-19 - coronavirus disease 2019} \\
\hline
\end{tabular}

